\title{
Energy Use and Human Health Nexus in Pakistan
}

\author{
Noreen Safdar ${ }^{a}$, Hala Asif ${ }^{b}$, Fatima Farooq ${ }^{c}$ \\ ${ }^{a}$ Assistant Professor, Department of Economics, The Women University Multan, Pakistan \\ E-mail: noreen.safdar@wum.edu.pk \\ ${ }^{\mathrm{b}}$ M.Phil. scholar Department of Economics, The Women University Multan, Pakistan \\ ${ }^{c}$ Assistant Professor, School of Economics, Bahauddin Zakariya University Multan, Pakistan \\ E-mail: fatimafarooq@bzu.edu.pk
}

\begin{tabular}{|c|c|}
\hline E DETAILS & ABSTRACT \\
\hline & \multirow{8}{*}{$\begin{array}{l}\text { This study finds the impact of coal energy (a kind of non-renewable } \\
\text { energy), renewable energy, Greenhouse gases, industrialization, } \\
\text { population growth and environmental degradation and on the health of } \\
\text { human beings, with the key emphasis on Tuberculosis incidence in } \\
\text { Pakistan for the time span } 1986 \text { to 2017. For a deep practical insight, the } \\
\text { study develops a system Auto-Regressive Distributed Lag (ARDL) model. } \\
\text { The results report that with an increase in the usage of coal energy, the } \\
\text { incidence of Tuberculosis also increases. In addition, the results also } \\
\text { highlight that by turning to the renewable energy (energy by sun, wind } \\
\text { and air) the health could be improved as the renewable energy is } \\
\text { environment friendly and it does not generate greenhouse gases and it } \\
\text { also does not cause environmental degradation. So, renewable energy } \\
\text { serves as helping factor to reduce the occurrence of Tuberculosis in } \\
\text { Pakistan. Moreover, the renewable energy is serving to lessen the } \\
\text { greenhouse gas emission and it also serves to lessen the environmental } \\
\text { degradation in Pakistan. On the contrast, the coal energy is causing } \\
\text { environmental degradation by increasing the amount of Greenhouse gas } \\
\text { emissions in the atmosphere which in turn causes Tuberculosis in } \\
\text { Islamic Republic of Pakistan. }\end{array}$} \\
\hline Accepted 18 July 2020 & \\
\hline $\begin{array}{l}\text { Available Online } 30 \text { September } \\
2020\end{array}$ & \\
\hline & \\
\hline $\begin{array}{l}\text { Energy Use, Renewable Energy, } \\
\text { Coal Energy, Human Health, } \\
\text { Tuberculosis }\end{array}$ & \\
\hline & \\
\hline & \\
\hline $0.47067 / \mathrm{r}$ & \\
\hline
\end{tabular}

(C) 2020 The authors. Published by SPCRD Global Publishing. This is an open access article under the Creative Commons Attribution-

NonCommercial 4.0

Corresponding author's email address: fatimafarooq@bzu.edu.pk

\section{Introduction}

Energy use is vital for the development of any country as it provides the base for development in all sectors of economy. Yet the benefits of using energy in all economies may differ because there is difference in usage of energy and types of energy that are used also may differ among countries. Mostly developed and well-developed countries use environment friendly energy sources, these are; renewable energy sources and thus they generate very low air pollution as compared to developing as well as poor countries where cheap and non-renewable energy sources are used for production of energy. 


\section{Review of Economics and Development Studies, Vol. 6 (3) 2020, 661- 674}

Increase in energy generation is beneficial for development of an economy as it guarantees economic growth and its effect on well-being of residents of a country, on environment and on the health of people is positive. But the non-renewable energy sources like coal, animal dung, wood, fossil fuels and some others may have positive relation with economic growth but has negative health impacts. Although it is seen that more developed countries used environment friendly energy sources as compared to developing or less developed countries.

Greenhouse gas is the combination of Carbon Dioxide gas $\left(\mathrm{CO}_{2}\right)$, Nitrous Oxide $\left(\mathrm{NO}_{2}\right)$, Sulphur Dioxide $\left(\mathrm{SO}_{2}\right)$ and other energy related emissions like Methane etc. The non-renewable energy sources generate the Greenhouse Gas (GHG) emissions which are the main cause of environmental degradation and air pollution which in turns causes mortality from respiratory, heart and other serious diseases like cancer and Tuberculosis etc.

As the use of energy is increasing day by day because the population is increasing so the demand for energy has increased almost 10 folds in previous some decades. And as Pakistan is a developing country, there is also an increase in industrialization so, the demand for energy can never be avoided. Demand for energy is snowballing at the increasing rate so, with the intention of meet the increasing demand of energy the supply of energy is also growing. The renewable energy use is growing in industrial sector, but the use of non-renewable energy is also growing at the increasing rate.

The air pollution is a great challenge for developed as well as developing world now a-days. The textile mills also contribute to air pollution as presence of Particulate Matters air pollutants are observed in textile mills areas. As the WHO health report, the Particulate Matters air pollutants in air has increased 5 percent from the year 2008 to 2015 in host country due to increase in traffic on roads and due to industrialization. Because of Small size of these particles they entered easily in to lungs through air and causes respiratory diseases like Asthma, Lung Cancer and other chronic and heart diseases (Niaz 2016).

In host country both kind of energy is used. Renewable energy comprises of high share in energy generation and in energy consumption also, but the share of non-renewable energy can also not be avoided. In our rural areas most of population is still engaged in conventional methods to get energy, they use biomass to get energy for heating and cooking. The harmful gases and substances that emits from biomass combustion are damaging environment and hence they have clearly negative health outcomes in the form of respiratory illness.

In host country industrialization is increasing so, the use of energy is also increasing in this regard. The population is also increasing and mostly the population in rural areas is increasing at high rate so, the use of non-renewable energy specially use of wood and coal is swelling which in turn causes an increase in Greenhouse Gas emissions in host country and it contributes to air pollution and causes lung and respiratory illness.

\section{Literature Review}

Kim et al. (2011) investigated the correlation between diseases and air pollution due to the usage of biomass fuels to get energy. At that time early one-third of total population in the world was using biomass to get energy domestically. The dependent variables like carbon monoxides, nitrogen dioxides, Particulate Matters etc. and independent variables like tuberculosis, pneumonia, respiratory diseases, chronic pulmonary obstructive disease, lung cancer, asthma and low birth weights etc. were 
Review of Economics and Development Studies, Vol. 6 (3) 2020, 661- 674

used in this study. The results of study demonstrated that usage of biomass as a fuel was proved dangerous to human health of not only for children but also for adults and it was the cause of mortality and morbidity.

Janjua et al. (2012) examined the use of biomass fuel and Acute Respiratory illness among children less than 5 years in rural Pakistan for the year 2007. Poisson Regression Model was used to access the connotation between the usage of Biomass fuel and Acute Respiratory Infection among children. The results indicated that the Acute Respiratory Infection was presented among children who accompanied their mothers during cooking and where the biomass such as fossil fuels was used as cooking fuel.

Vieux et al. (2012) investigated the correlation between the greenhouse gas emissions and selfselected individual's diet. They took the data of France for analysis in this study. The Linear Regression model was being used for analysis. The results showed that if food items were substituted like the meat was replaced with vegetables and fruits, the health benefits could be gained but it is not necessary that food associated greenhouse gas emission would be decreased.

Scarborogh et al. (2012) investigated the health consequence of energy that was used as cooking fuel for cooking mostly meat and dairy products in United Kingdom. The main reason of Greenhouse emissions in United Kingdom was cooking system as it contributed one-fifth of greenhouse gas emissions, these emissions in turn caused environmental pollution and caused serious ill health effects. The results predicted that there was positive impact of these emissions on human health and these were the cause of mortality from cardiovascular disease and cancer.

Pop and Dockery (2012) explored the impact of fine Particulate air pollution on human health. Auto Regressive Distributed Lag Model ARDL was being used in this analysis to evaluate longer scale time series data. The results revealed that the adverse health effects were caused by the exposure concentration of air pollutants and also on exposure length of these pollutants. There were also some suggestions to improve air quality like there should be a reduction in energy use.

Macdiarmid et al. (2012) estimated the relationship between the greenhouse gas and healthy diet for United Kingdom. The purpose of this study was to estimate the improvement in food choices by reducing the Greenhouse gases, and the food must be balanced according to diet requirements of health. The Linear Programming Optimization Model was being used for estimation. The results showed that the sustainable diet could be attained by lowering greenhouse gas emissions and by not eliminating meat and dairy products and by not increasing the cost of consumers on these products.

Rao et al. (2013) investigated the relation between the better air and health. The study addressed the policies on clean fuels, air pollution and climate change and impacts of these policies on human health. This review derived much of information from the Global Energy Assessment. The results showed that air pollution was the main cause of burden of disease. There are some policy measures that suggested that there should be reduction in both indoor and outdoor air pollution and if there will be reduction in the outdoor as well as indoor air pollution, so the health level will be improved.

Jensen et al. (2013) estimated the health co-benefits of decreases in greenhouse gas emissions strategies and the study suggested some targets to lessen greenhouse gas emissions till 2030. The results revealed that if there were reductions in greenhouse gas emissions there were improvement in 


\section{Review of Economics and Development Studies, Vol. 6 (3) 2020, 661- 674}

health standard. The results also suggested that the urban transport strategy and food and agriculture strategies must be adopted to lessen greenhouse gas emissions and to bring health benefits worldwide.

Smith et al. (2014) investigated the reduction strategies of short-lived greenhouse pollutants and their impacts on public health. Black carbon, ozone and sulfates are known as short-lived greenhouse pollutants and they emitted widely from fuel. The results revealed that, all greenhouse short-lived pollutants had negative health effects either they were used for warming or cooling, and other long-lived pollutants had little direct effects on human health. So, the policy measures suggested that there should be some strategies to minimize the use of short-lived greenhouse pollutants so that the health benefits could be gain.

Amanat et al. (2015) estimated the rising level of Particulate Matter $_{2.5}$ from different cooking fuels in rural areas of Punjab, Pakistan. This study used the data of a small rural area Allah Abad of Kasur district, there three residential houses were selected with different types of solid fuels usage. The results showed that using wood as a fuel for cooking emitted 34 times more Particulate Matters as recommended by World Health Organization WHO. It is recommended that cleaner fuel should be used because they generated less Particulate Matters as compared to biomass fuels.

Niaz et al. (2016) investigated the Particulate Matters $\mathrm{PM}_{10}$ and $\mathrm{PM}_{2.5}$ and they compared both by taking the data of two different countries China and Pakistan. Both the cities were known as hub to textile so there the energy consumption was very high, Particulate Matters in air increased as the development in textile. The results revealed that both the $\mathrm{PM}_{1.0}$ and $\mathrm{PM}_{2.5}$ were high in winter season as compared to summer season, and the variations in PM level were higher in Dalian as compared to Faisalabad due to more energy use.

Hanif (2018) estimated the habits of energy usage by humans and its impacts on human health in Sub-Saharan Africa for the time span from 1995 to 2015. The Generalized Method of Moments (GMM) was used by author for analysis of data. The results of this study declared that the use of both solid fuels and fossil fuels for cooking, heating and lightening etc. in Sub-Saharan Africa caused Tuberculosis among human beings and also these fuels reduced life expectancy as these caused mortality. On the other hand, the results showed that by using renewable energy sources like wind, air and water the positive health outcomes was gained as the renewable energy sources was not the cause of carbon and another greenhouse gas emission.

Nguyen et al. (2018) discovered the effect of carbon dioxide emissions on economic growth in the case of Vietnam from the period of 1986 to 2015. Autoregressive Distributed Lag model was used to estimate carbon dioxide emissions, gross domestic product per capita growth and net official development assistance. Whereas, carbon dioxide emission was used as a dependent and gross domestic product was used as an independent variable. The finding showed that air pollution and growth level had a significant relationship in Vietnam. Furthermore, this study also concluded that carbon dioxide emissions had a negative effect on economic growth in the long run.

Safdar et al. (2019) investigated the impact of energy consumption, environmental degradation on employment in 50 developing countries over the period of 1990 to 2016. By using PMG method, the study came to conclusion that energy use and environmental degradation is great threat to human health and quality of life. The study suggested that these countries should adopt renewable energy sources to meet their energy demand. The dependence on renewable energy sources will enhance growth and other economic opportunities without affecting human health and environment. 


\section{Data and Methodological Issues}

This section describes the variables that are being used to find out the impacts of energy use on human health in Pakistan. On the basis of theoretical and empirical significance, the variables are chosen. The Tuberculosis is used as dependent variable and renewable energy, coal consumption, Greenhouse Gas, Industrialization, population and Environmental Degradation are the explanatory variables.

\section{a) Time Period:}

The time series data of Pakistan for the time period 1975-2017 is used to check the connection among dependent and explanatory variables.

\section{b) Data Sources:}

This study is based on the secondary type of data and the data is gathered from WDI (World Development Indicator 2017), WHO (World Health Organization) and Economic Survey of Pakistan.

\section{c) Model Specification:}

The study shows the impacts of energy use on human health. Model specification is as follows.

$\mathrm{TB}=f(\mathrm{ENG}, \mathrm{CLC}, \mathrm{GHG}, \mathrm{IND}, \mathrm{POP}, \mathrm{ENV})$

Here, Tuberculosis is the function of Renewable energy use, Coal consumption, Greenhouse Gas, Industrialization, Population and environmental Degradation.

$$
\mathrm{LTB}=\beta \mathrm{O}+\beta_{1}(\mathrm{LENG})+\beta 2(\mathrm{LCLC})+\beta 3(\mathrm{LGHG})+\beta_{4}(\mathrm{LIND})+\beta 5(\mathrm{LPOP})+\beta 6(\mathrm{LENV})+\varepsilon
$$

Whereas,

$\mathrm{LTB}=\log$ of Tuberculosis

LENG = log of Renewable Energy use

$\mathrm{LCLC}=\log$ of Coal Consumption

$\mathrm{LGHG}=\log$ of Greenhouse Gas

LIND: $\log$ of Industrialization

LPOP: $\log$ of Population

LENV: log of Environmental Degradation

Here $\beta$ 's are the elasticities. Keeping in view of above model we evaluated the model to satisfy the hypothesis of study that is; the coal energy use is positively related to tuberculosis and renewable energy use is negatively related to tuberculosis incidence. Industrialization, Greenhouse gas, industrialization and Environmental degradation are positively related to Tuberculosis incidence and negatively or positively related to Tuberculosis.

\section{Results and Discussion}

This section gives the unit root and ARDL estimates of the model. The results are as follows:

\subsection{Unit Root test:}

To check the data is stationary or not we use panel unit root test presented by Dickey and Fuller. The result obtained by this test is as follows. 
Review of Economics and Development Studies, Vol. 6 (3) 2020, 661- 674

Table 1: Unit Root Results:

\begin{tabular}{|c|c|c|c|c|c|}
\hline \multirow[t]{2}{*}{ Variables } & \multicolumn{2}{|l|}{ Level } & \multicolumn{2}{|c|}{$1^{\text {st }}$ difference } & \multirow{2}{*}{$\begin{array}{l}\text { Results } \\
\text { Conclusion } \\
\end{array}$} \\
\hline & intercept & Trend and intercept & intercept & Trend and intercept & \\
\hline TB & ----- & ---- & $\begin{array}{l}-2.960 \\
(0.0001)\end{array}$ & ----- & I (1) \\
\hline ENG & ---- & ---- & $\begin{array}{l}-2.960 \\
(0.002)\end{array}$ & ----- & I (1) \\
\hline CLC & ---- & ----- & $\begin{array}{l}-2.992 \\
(0.0001)\end{array}$ & ----- & I (1) \\
\hline ENV & $\begin{array}{l}-2.9604 \\
(0.0002)\end{array}$ & ----- & ----- & ----- & I (o) \\
\hline IND & ----- & ----- & $\begin{array}{l}-2.9678 \\
(0.0000)\end{array}$ & ----- & I (1) \\
\hline GHG & ----- & ----- & $\begin{array}{l}-2.9639 \\
(0.0000)\end{array}$ & ----- & I (1) \\
\hline POP & ----- & ----- & $\begin{array}{l}-2.9639 \\
(0.0000)\end{array}$ & ----- & I (1) \\
\hline
\end{tabular}

Source: estimated by author using E-views 9.

The results show the mixed order of integration so we used Auto Regressive Lag Model ARDL to find the relationship among variables we used in our model.

\subsection{ARDL Estimates of Model:}

The results of unit root showed the mix order of integration, so ARDL is suitable proposed technique to estimate long run and short association among variables. Before going to discuss the ARDL results, it is necessary to find the long run assessment of association between series of variables, the bound test estimation is demonstrated for this purpose.

Table 2: Bound Testing

\begin{tabular}{|c|c|c|c|c|c|}
\hline \multirow{3}{*}{ F-statistics } & \multirow{3}{*}{3.922196} & \multicolumn{2}{|c|}{ At $5 \%$ significance level } & \multicolumn{2}{|c|}{ At $10 \%$ significance level } \\
\hline & & $\begin{array}{l}\text { Lower } \\
\text { bound }\end{array}$ & $\begin{array}{l}\text { Upper } \\
\text { bound }\end{array}$ & $\begin{array}{l}\text { Lower } \\
\text { bound }\end{array}$ & $\begin{array}{l}\text { Upper } \\
\text { bound }\end{array}$ \\
\hline & & 2.45 & 3.61 & 2.12 & 3.23 \\
\hline
\end{tabular}

\subsubsection{ARDL Long Run \& Short Run Estimates:}

Table 3 gives the long run and short run estimates of ARDL are given in 
Table 3: ARDL Estimates of Model:

\begin{tabular}{|l|l|l|l|l|}
\hline \multicolumn{5}{|c|}{ ARDL Long Run Results } \\
\hline Variables & Coefficient & $\begin{array}{l}\text { Standard } \\
\text { Error }\end{array}$ & t-statistics & Probability \\
\hline ENG & -1.624645 & 0.816680 & 0.912637 & 0.07 \\
\hline CLC & 0.109996 & 0.049348 & 0.912637 & 0.04 \\
\hline GHG & 1.068780 & 0.378509 & 2.823662 & 0.01 \\
\hline IND & 0.582122 & 0.264541 & 2.200499 & 0.05 \\
\hline POP & 2.201759 & 0.912637 & -2.412525 & 0.03 \\
\hline ENV & 0.219598 & 0.912637 & 0.451768 & 0.06 \\
\hline & & Short Run Results & \\
\hline Variables & Coefficients & Std-Error & t-statistics & Probability \\
\hline D(TB(-1)) & -1.013373 & 0.299638 & -3.381995 & 0.00 \\
\hline D(TB(-2)) & -0.537085 & 0.213343 & -2.517473 & 0.02 \\
\hline D(ENG) & -0.120812 & 0.304756 & -0.396424 & 0.69 \\
\hline D(CLC) & -0.054587 & 0.021322 & -2.560082 & 0.02 \\
\hline D(GHG) & -0.893455 & 0.249706 & -3.578027 & 0.00 \\
\hline D(IND) & -0.032171 & 0.053762 & -0.598402 & 0.56 \\
\hline D(IND(-1)) & 0.044297 & 0.046694 & 0.948646 & 0.36 \\
\hline D(POP) & 4.918000 & 1.420144 & 3.463029 & 0.00 \\
\hline D(POP(-1)) & 1.524614 & 1.564190 & 0.974698 & 0.35 \\
\hline D(ENV) & 0.227364 & 0.179348 & 1.267727 & 0.23 \\
\hline D(ENV(-1)) & 0.486843 & 0.093286 & 5.218817 & 0.00 \\
\hline CointEq(-1) & -0.496263 & 0.217480 & 2.281883 & 0.04 \\
\hline & & & & \\
\hline
\end{tabular}

We take Tuberculosis as a dependent variable that we used for the proxy of human health. Renewable energy use has positive and significant relationship with Tuberculosis; a respiratory disease. The coefficient value of renewable energy is positive and significant with Tuberculosis at 10\% level of significance. $1 \%$ increase in renewable energy consumption causes $-1.62 \%$ reduction in Tuberculosis incidence rate. Our results accomplish that by using renewable energy like energy generated from wind, sun air etc. the health of human beings improves and respiratory illness like Tuberculosis is reduced. Our result is supported by the work of Hanif (2018).

The Coal energy consumption has positive and significant relation with Tuberculosis at $5 \%$ level of significance. The results show that $1 \%$ increase in the consumption of coal energy causes $0.11 \%$ increase in respiratory illness. Our result indicates that biomass fuel like coal energy use is the cause of respiratory diseases. Our result is supported by the studies for [Hendryx et al. (2008); Janjua et al (2012) and Hanif (2018)].

According to the World Health Organization's report, the Tuberculosis s caused by using biomass fuel WHO (2006). Greenhouse Gas has positive and significant relation with Tuberculosis which indicates that 1\% Increase in Greenhouse Gas causes 1.07\% increase in Tuberculosis. Our result shows 
Review of Economics and Development Studies, Vol. 6 (3) 2020, 661- 674

that by the increase in non-renewable energy consumption the Greenhouse Gas's quantity in air also increase and Greenhouse Gas causes respiratory illness among humans. Our results are supported by the contribution of [Vieux et al. (2012) and Scarborough et al. (2012)].

Industrialization has positive and significant relation with Tuberculosis. The coefficient value of Industrialization is 0.58 so it has statistically significant relationship with Tuberculosis which means that $1 \%$ increase in Industrialization causes of $0.58 \%$ increase in respiratory illness. Our result shows that as the industrialization is increasing so, the use of energy in industry is also increasing which is the cause of air pollution and causes respiratory illness. Our result is supported by the work of many studies. [Yousufzai et al (2000); Bang (2005); Babalik (2011) and Niaz et al. (2016)].

Population has positive and significant relation with Tuberculosis. The coefficient value of Population has statistically significant relationship with Tuberculosis which shows that $1 \%$ increase in Population causes $2.20 \%$ increase in respiratory illness. As population of host country cause increase in the Tuberculosis because it is a communicable disease which is causes by interaction of humans with each other. Another reason is that as the population increases, the energy use also increases by same or more ratio, which is the cause of air pollution and environmental degradation which in turn causes respiratory diseases among human beings. Our results are supported by numerous studies. [Dowdy et al. (2013); Hanif (2018)].

The Environmental degradation has positive and significant relationship with Tuberculosis. The coefficient value of Environmental Degradation is 0.21 which shows that Environmental degradation has statistically significant relationship with Tuberculosis and $1 \%$ increase in Environmental degradation causes $0.21 \%$ increase in Tuberculosis. Our results states that as the energy use increases the environmental degradation increases which causes serious respiratory illness specially it is the cause of Tuberculosis. Our results are supported by the work of Samet et al. (2000) and Hanif (2018).

The short run estimates of this model show that some variables like CLC, GHG, POP and EVD at lag are significant but signs are mixed. The coefficient value of coint-Eq(-1) is -0.49 that which is negative and statistically significant which shows long run adjustment.

\subsubsection{Diagnostic Analysis of the Model:}

We estimate the serial correlation and heteroskedasticity of model. Different methods are applied to check the heteroskedasticity and auto-correlation in the model; most widely hired methods are BreushGodfrey correlation LM test and heteroskedasticity diagnostic test.

\section{Table 4: Auto correlation and Heteroskedasticity diagnostics}

\begin{tabular}{|l|l|l|}
\hline Name of test & F-statistics value & Probability \\
\hline $\begin{array}{l}\text { Breush-Godfrey } \\
\text { correlation LM test }\end{array}$ & 1.894737 & 0.2057 \\
\hline Heteroskedasticity & 0.907657 & 0.5847 \\
\hline
\end{tabular}

Source: estimated by author using E-views 9.

In this model, the F-statistics value of serial correlation is 1.8947 and the probability is 0.2057 which is statistically insignificant So, we reject our null hypothesis that there is serial correlation exists and we accept our alternative hypothesis that there no serial correlation in this model. The F-statistics 


\section{Review of Economics and Development Studies, Vol. 6 (3) 2020, 661- 674}

value of heteroskedasticity is 0.907657 and probability is 0.5847 which is insignificant, we reject our null hypothesis and accept our alternative hypothesis that is there is no heteroskedasticity exists in our model.

\subsection{Causality Test:}

Granger Causality test is used to explain the casual link among tuberculosis incidence and selected independent variables.

The causality results identify that there is no causality between TB and renewable energy use, CLC, IND and POP while there is unidirectional causality between TB and GHG, according to our results the unidirectional causality between TB and GHG is noticed. According to our results, there is unidirectional causality between TB and EVD. There exits unidirectional causality between POP and ENG, IND and CLC and POP and CLC. There is bidirectional causality relation among POP and IND. The unidirectional causality between ENV and POP, and between ENV and IND is also found. (see table A.1 in appendix).

\section{Conclusion and Policy Implications:}

The principle aim of the given research is to notice the influence of energy use on the human health. For this purpose, the secondary data of Pakistan is taken from different sources e.g. WDI, WHO and Economic Survey of Pakistan from the time span 1996-2017.

This study documented renewable and non-renewable energy usage by both industrial and household sector and it also discussed the effects of both kinds of energy on the health of humans. Energy gained by renewable energy sources like sun, wind and air provides no harms to human health as it does not contribute to Greenhouse Gas emissions. But the energy gained by non-renewable energy sources especially by using coal, is harmful for the environment as well as for the health of residents of host country. In host country, most of the population resides in rural areas and they fulfill most of their energy need by burning of coal. It is true that in host country both kinds of energy sources are being employed to fulfill the need of energy so both kinds of energy are analyzed in this study. And it is evident by many studies that coal generated pollutants can travel very quickly as compared to other air pollutants.

Tuberculosis is one of the respiratory diseases; it is proved from previous studies that coal use is the cause of respiratory diseases. Coal energy that is used by households or industrial sector both generates the Greenhouse gases and it causes the huge amount of air pollutants that is the cause of Tuberculosis among residents of that areas. Our results are supported by (Janjua et al., 2008). In host country the renewable energy is also used by residents and it is also consumed by industrial sector. In the analysis we found that there is a negative relation between renewable energy use and Tuberculosis, by the usage of renewable energy sources to get energy the respiratory health of people could not be damaged. Our result is supported by the contributions of Hanif (2018).

\section{Policy Recommendations:}

Here are some predictions that we made after analyzing the current situation of the host country. Some of these prophecies are as follows.

- Analyzing the last year's estimates, the coal use will be increase in host country, as in host country the coal power plant is also constructed in Sahiwal in 2017.

- Although the cheapest source of energy in host country is coal. So, the coal use will also increase as mostly the population is poor and there is also no close substitute that is also as cheap as coal. 


\section{Review of Economics and Development Studies, Vol. 6 (3) 2020, 661- 674}

- There is a very huge increase in the amount of Greenhouse Gas emissions in host country from 1990 to onwards. Now the greatest source of Greenhouse Gas emissions is the energy sector. So as the population is increasing at a rapid rate so that the energy use will also increase, Greenhouse Gas emissions will also increase.

- As the demand for coal energy will increase the Greenhouse Gas emissions will also generates to large quantity that will damage the environment and these emissions will cause the respiratory illness like Tuberculosis

Now here are some policy measures that should be beneficial for policy makers to make policies that may prove helpful to reduce the health damage caused by energy usage. Some of these recommendations are as follows.

- We should turn to renewable energy sources from non-renewable energy sources as the health cost of non-renewable energy is very high.

- The environment friendly energy generation techniques must be adopted to reduce the air pollution and Greenhouse Gas emissions.

- To improve the health conditions of people living in rural areas the Govt. should provide cheap and renewable energy to them, this step will be beneficial for rural population if they turn to renewable energy from biomass combustion.

- In industrial sector the access to renewable energy should be cheaper so that this sector could move to renewable energy and the Greenhouse Gas emissions could be decreased.

- It is endorsed that the best understanding or fuel selection to get energy should be developed among all energy consuming sectors, so that they could move to environment friendly energy sources and the burden of disease could be minimized.

- It is recommended that the access to renewable energy should be cheaper than any nonrenewable energy source so that urban as well as rural population could gain its benefits and the burden of disease could be lessened.

- It is suggested to improve the ventilation quality, it will be beneficial for the improvement of indoor air quality.

\section{References}

Bui, X. T., Nguyen, T. T., Nguyen, D. D., \& Dao, T. S. (2018). Effects of nutrient ratios and carbon dioxide bio-sequestration on biomass growth of Chlorella sp. in bubble column photobioreactor. Journal of environmental management, 219, 1-8.

Hanif, I. (2018). Energy consumption habits and human health nexus in Sub-Saharan Africa. Environmental Science and Pollution Research, 25(22), 21701-21712.

Janjua, N. Z., Mahmood, B., Dharma, V. K., Sathiakumar, N., \& Khan, M. I. (2012). Use of biomass fuel and acute respiratory infections in rural Pakistan. Public health, 126(10), 855-862.

Jensen, H. T., Keogh-Brown, M. R., Smith, R. D., Chalabi, Z., Dangour, A. D., Davies, M., ... \& Hamilton, I. (2013). The importance of health co-benefits in macroeconomic assessments of UK Greenhouse Gas emission reduction strategies. Climatic change, 121(2), 223-237.

Macdiarmid, J. I., Kyle, J., Horgan, G. W., Loe, J., Fyfe, C., Johnstone, A., \& McNeill, G. (2012). Sustainable diets for the future: can we contribute to reducing greenhouse gas emissions by eating a healthy diet? The American journal of clinical nutrition, 96(3), 632-639.

Nasar, Z. A., Amant, H., Ali, Z., Sidra, S., \& Colbeck, I. (2015, June). PM2. 5 arising from different cooking fuels in rural residential houses. Pakistan Agricultural Scientists Forum.

Niaz, Y., Zhou, J., Nasir, A., Iqbal, M., \& Dong, B. (2016). Comparative study of particulate matter (PM 10 and PM 2.5) in Dalian-China and Faisalabad-Pakistan. Pakistan Journal of Agricultural Sciences, 53(1). 


\section{Review of Economics and Development Studies, Vol. 6 (3) 2020, 661- 674}

Pope III, C. A., \& Dockery, D. W. (2012). Health effects of fine particulate air pollution: lines that connect. Journal of the air \& waste management association, 56(6), 709-742.

Rao, S., Pachauri, S., Dentener, F., Kinney, P., Klimont, Z., Riahi, K., \& Schoepp, W. (2013). Better air for better health: Forging synergies in policies for energy access, climate change and air pollution. Global Environmental Change, 23(5), 1122-1130.

Safdar, N., Chaudhry, I. S., \& Chaudhry, M. O. (2019). Energy Consumption, Environmental Degradation and Economic Growth in Developing Countries. Pakistan Journal of Social Sciences (PJSS), 39(2).

Scarborough, P., Allender, S., Clarke, D., Wickramasinghe, K., \& Rayner, M. (2012). Modelling the health impact of environmentally sustainable dietary scenarios in the UK. European journal of clinical nutrition, 66(6), 710.

Smith, K. R., Jerrett, M., Anderson, H. R., Burnett, R. T., Stone, V., Derwent, R., ... \& Pope III, C. A. (2014). Public health benefits of strategies to reduce greenhouse-gas emissions: health implications of short-lived greenhouse pollutants. The lancet, 374(9707), 2091-2103.

Vieux, F., Darmon, N., Touazi, D., \& Soler, L. G. (2012). Greenhouse gas emissions of self-selected individual diets in France: changing the diet structure or consuming less? Ecological economics, 75, 91-101. 
Review of Economics and Development Studies, Vol. 6 (3) 2020, 661- 674 Appendix

\section{A.1 Granger Causality Results}

\begin{tabular}{|c|c|c|c|}
\hline \multirow{2}{*}{ Null Hypothesis: } & \multirow[b]{2}{*}{ Obs } & \multirow{2}{*}{ F-Statistic } & \multirow{2}{*}{ Prob. } \\
\hline & & & \\
\hline ENG does not Granger Cause TB & 30 & 2.12872 & 0.1401 \\
\hline \multicolumn{2}{|l|}{ TB does not Granger Cause ENG } & 0.74227 & 0.4862 \\
\hline CLC does not Granger Cause TB & 30 & 0.01111 & 0.9890 \\
\hline \multicolumn{2}{|l|}{ TB does not Granger Cause CLC } & 1.33539 & 0.2812 \\
\hline IND does not Granger Cause TB & 30 & 0.00039 & 0.9996 \\
\hline \multicolumn{2}{|l|}{ TB does not Granger Cause IND } & 1.72962 & 0.1979 \\
\hline POP does not Granger Cause TB & 30 & 0.41507 & 0.6648 \\
\hline \multicolumn{2}{|l|}{ TB does not Granger Cause POP } & 0.44477 & 0.6459 \\
\hline GHG does not Granger Cause TB & 30 & 1.09928 & 0.3487 \\
\hline \multicolumn{2}{|l|}{ TB does not Granger Cause GHG } & 2.76850 & 0.0820 \\
\hline ENV does not Granger Cause TB & 30 & 1.53149 & 0.2358 \\
\hline \multicolumn{2}{|l|}{ TB does not Granger Cause ENV } & 2.58731 & 0.0952 \\
\hline CLC does not Granger Cause ENG & 30 & 0.57627 & 0.5693 \\
\hline \multicolumn{2}{|l|}{ ENG does not Granger Cause CLC } & 1.87103 & 0.1749 \\
\hline IND does not Granger Cause ENG & 30 & 0.13767 & 0.8720 \\
\hline \multicolumn{2}{|l|}{ ENG does not Granger Cause IND } & 3.66298 & 0.0403 \\
\hline POP does not Granger Cause ENG & 30 & 0.02154 & 0.9787 \\
\hline \multicolumn{2}{|l|}{ ENG does not Granger Cause POP } & 3.80675 & 0.0360 \\
\hline GHG does not Granger Cause ENG & 30 & 23.3468 & 2.E-06 \\
\hline \multicolumn{2}{|l|}{ ENG does not Granger Cause GHG } & 2.06832 & 0.1475 \\
\hline ENV does not Granger Cause ENG & 30 & 0.68889 & 0.5114 \\
\hline \multicolumn{2}{|l|}{ ENG does not Granger Cause ENV } & 0.17064 & 0.8441 \\
\hline IND does not Granger Cause CLC & 30 & 4.92809 & 0.0157 \\
\hline \multicolumn{2}{|l|}{ CLC does not Granger Cause IND } & 0.41992 & 0.6616 \\
\hline POP does not Granger Cause CLC & 30 & 2.73744 & 0.0841 \\
\hline
\end{tabular}


Review of Economics and Development Studies, Vol. 6 (3) 2020, 661- 674

\begin{tabular}{|c|c|c|c|}
\hline CLC does not Granger Cause POP & & 0.33919 & 0.7156 \\
\hline GHG does not Granger Cause CLC & 30 & 2.30695 & 0.1204 \\
\hline CLC does not Granger Cause GHG & & 1.24653 & 0.3048 \\
\hline ENV does not Granger Cause CLC & 30 & 0.07030 & 0.9323 \\
\hline CLC does not Granger Cause ENV & & 0.34358 & 0.7125 \\
\hline POP does not Granger Cause IND & 30 & 2.65359 & 0.0901 \\
\hline IND does not Granger Cause POP & & 3.17206 & 0.0592 \\
\hline GHG does not Granger Cause IND & 30 & 1.92888 & 0.1663 \\
\hline IND does not Granger Cause GHG & & 1.10014 & 0.3484 \\
\hline ENV does not Granger Cause IND & 30 & 4.48062 & 0.0217 \\
\hline IND does not Granger Cause ENV & & 1.63063 & 0.2160 \\
\hline GHG does not Granger Cause POP & 30 & 1.36827 & 0.2730 \\
\hline POP does not Granger Cause GHG & & 0.30596 & 0.7391 \\
\hline ENV does not Granger Cause POP & 30 & $7 \cdot 70537$ & 0.0025 \\
\hline POP does not Granger Cause ENV & & 0.44930 & 0.6431 \\
\hline ENV does not Granger Cause GHG & 30 & 2.24650 & 0.1267 \\
\hline GHG does not Granger Cause ENV & & 2.20827 & 0.1309 \\
\hline
\end{tabular}

STABILITY TEST:

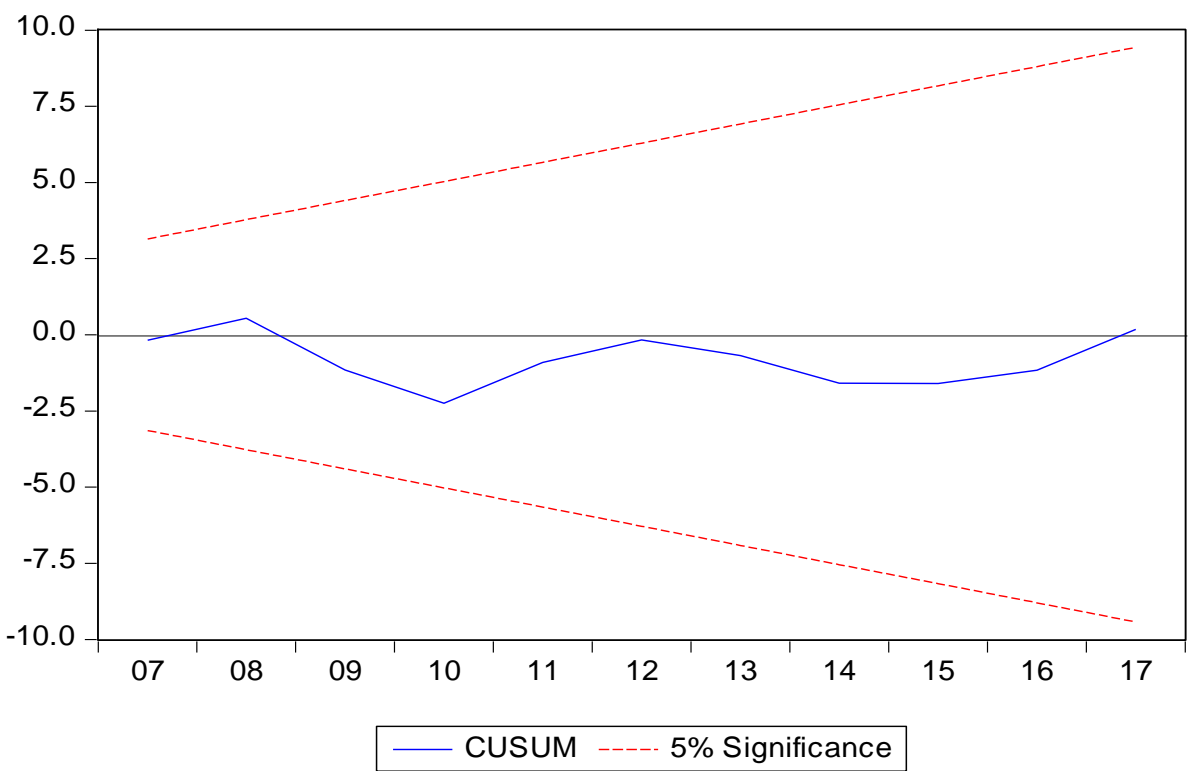

FIGURE 1. Plot of cumulative sum of recursive and residuals 
Review of Economics and Development Studies, Vol. 6 (3) 2020, 661- 674

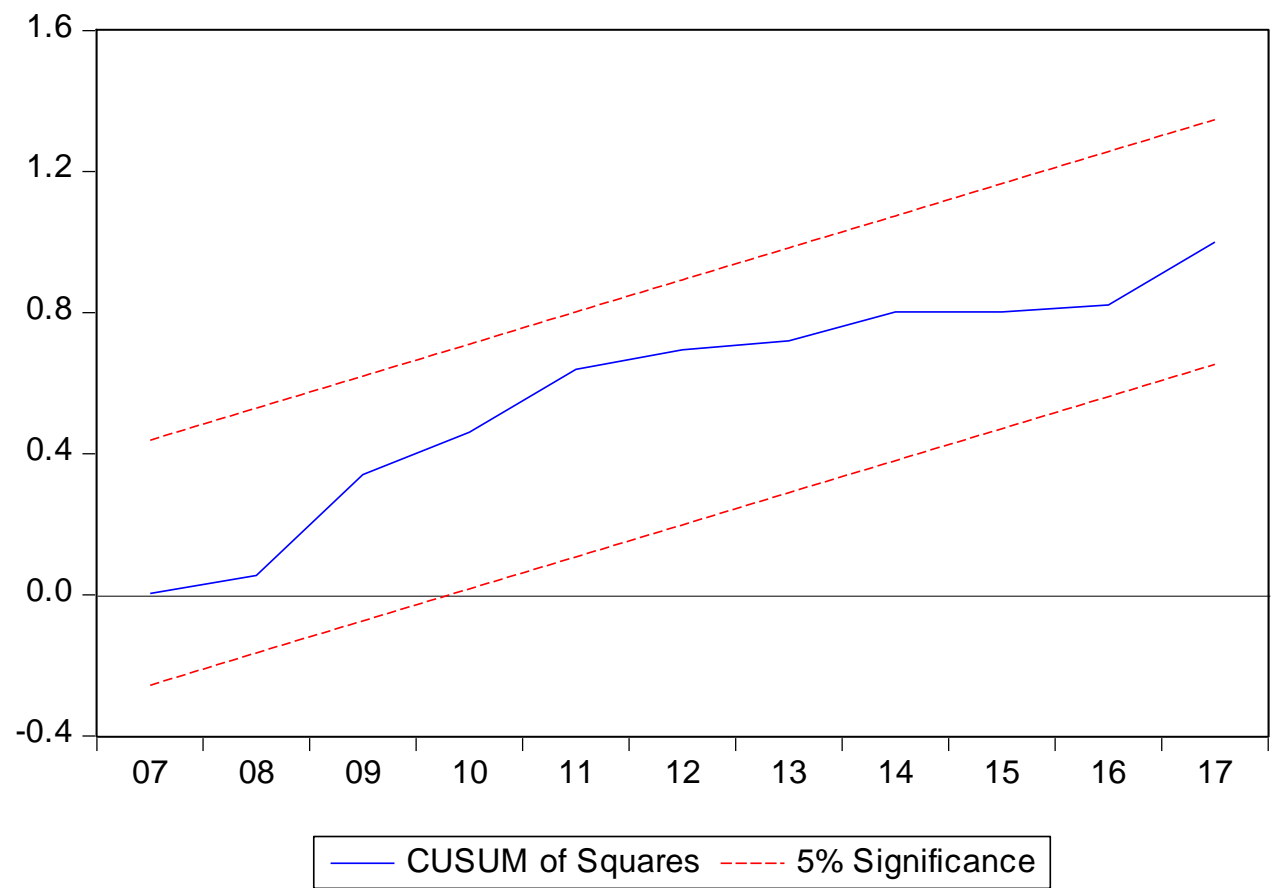

FIGURE 2. Plot of cumulative sum of recursive and residuals Source: estimated by author using E-views 9. 